\title{
The Effect of Constructivist Teaching Model on SSS Physics Students' Achievement and Interest
}

\author{
Dr. Ursula N. Akanwa, and Dr. Alphonsus O. Ovute \\ Department of Science Education College of Agricultural \& Science Education \\ Michael Okpara University of Agriculture; Umudike P. M. B. 7267; Umuahia, Abia State; Nigeria
}

\begin{abstract}
The effect of constructivist teaching model on senior secondary school physics students' achievement and interest was examined. Quasi-experimental design was employed. Using a stratified sampling technique, a sample of 160 SSS physics student were drawn, and categorized into experimental and control groups. The experimental group (80) was taught using constructivist approach while the control; group was taught the same physics concepts (waves and sound) using conventional (chalk board) approach. A validated physics achievement tests on the lessons covered were administered to both groups of students before and after the experiment. Also a researcher developed and validated interest inventory was administered to the two groups. Mean, standard deviation and $z$ statistics were tools for the data analysis. Findings revealed that constructivist approach had a significant effect on both the achievement and interest of SSS physics students. Based on the findings, some recommendations were made.
\end{abstract}

\section{Introduction}

Constructivists are of the opinion that learners interpret new experiences in the light of the already existing knowledge or experiences. The constructivist model therefore consists of teaching methods that foster learner's active participation during teaching and learning episode. Nwafor (2007) described constructivism as a theory that rests on the inmate human drive to make sense of the world. Also Wikipedia (2009) explained that the learner actively constructs knowledge by integrating new information and experience into what they have previously come to understand. Giving credence to the above, Oforma (2009) posits that learner should not be spoon fed, instead, the learner should be left to discover solutions by him/herself. Oforma (2009) further asserts that the message becomes effective when teaching rules and procedures involve that active participation of learners, stimulate their imagination, provoke and guide their thinking.

Presently, the teaching approach in the physics lessons in secondary school classrooms seems boring and uninteresting. This is particularly true when one considers that the conventional method of chalk, board and talk are predominantly in vogue. Notwithstanding the call for the use of modern approach in the form of constructivist view, many teachers still use the conventional approach. The question is: Can constructivist teaching model make a significant difference in the achievement of secondary school physics students? Moreover, as interest in a subject has been identified as correlating positively with achievement in such a subject, can constructivist teaching model produce a significance change in the interest of students towards the study of physics at secondary school level? The purpose of the study was to determine the effect of constructivist teaching model on SSS physics students' achievement and interest. The findings of the study will be significant to students and teaching of physics as it would expose them to the importance of the use of the constructivist model in teaching and learning. The policy makers as well as the educationists would benefit from the findings of the study as it would recommend strategies for remodeling the conventional teaching model to constructivist model.

\section{Research questions and}

1. What is achievement score of students taught SS physics using constructivist model and their counterparts taught using the conventional approach?

2. What is the interest score of students taught SS physics using constructivists teaching model and their counterparts taught using the conventional approach?

\section{Hypotheses}

1. There is no significant difference $(\mathrm{P}<0.05)$ in mean achievement score between the students taught using constructivist teaching approach and their counterparts taught using conventional approach.

2. There is no significant difference $(\mathrm{P}<0.05)$ in mean interest score between the students taught physics concepts using constructivist approach and their counterparts taught using conventional approach. 


\section{Method}

The study employed a quasi-experimental design-since intact classes of physics students were used. There was no randomization of the students into experimental and control groups. The study was carried out in Obollo- Afor Education Zone of Enugu State. The Obollo- Afor Education Zone is made up of 289 secondary schools with about 14,000 students in all as at 2008/09 session.

The population of the study was all the senior secondary two (SS2) physics students in all the public schools in Oboll-Afor Education Zone. The SS2 was chosen as the population because they are not exam class and have been to great extent taught physics concepts particularly, the wave and sound concepts used in the study.

Four secondary schools that have physics students in the SS2 class were sampled for the study. From each school, forty (40) SS physics students were drawn from the intact classes. A total of 160 physics students who were in the four sampled class formed the sample of the study.

The four (4) classes were categorized into the experimental and control groups of two (2) classes each. The experimental and control groups consisted of 80 students respectively.

Two instruments - the achievement test and interest scale instruments were developed and used for data collection. The physics achievement test that covered the waves and sound contents contained in the SS2 physics curriculum was developed. It was a thirty (30) items achievement test constructed using a table of specification.

The interest scale was developed based on literature reviewed and it was comprised of twenty (20) statement items cued both positively and negatively toward physics study.

The two instruments were subjected to face validation using three experts drawn from departments of Science Education, measurement and evaluation and educational foundations. The comments of the experts helped in the production of final version of instruments that were used to collect data on the issues of achievement and interest in physics.

The reliabilities of the instruments were also determined, using cronbachalpha for interest and kuderRichardson 20 for achievement test. The reliability values were 0.76 and 0.74 respectively for the achievement test and interest scales.

The experimental classes were taught the contents of waves and sound as contained in the SS2 physics curriculum for two weeks using the constructivist teaching model. Also the control group classes were taught the same physics contents using conventional teaching model of chalk, and talk for same period. A 30 item physics achievement test was administered to both groups by their regular teachers as posttest and the scores were recorded.

Further, the validated interest inventory was administered on both the control and experimental groups after the teaching was concluded. Their interest scores were also recorded.

Both the achievement test scores and interest scores were analyzed using mean, standard deviation and z-test.

\section{Results}

The results were presented according to the posed research questions and hypotheses as follows:

Research Question 1: what is the mean achievement scores of the SS students, when taught physics using constructivist teaching model and their counterparts taught using conventional teaching models?

Table 1 presents the mean scores and standard deviations (SD) of both the constructivist and conventional teaching model groups.

Table 1: Mean and Standard Deviation of Physics Student's Achievement Scores

\begin{tabular}{|l|l|l|l|}
\hline Group & No. of Students & Mean Score $(\mathbf{X})$ & Standard Deviation \\
\hline Constructivist model & 80 & 72.6 & 15.3 \\
\hline Conventional model & 80 & 50.1 & 16.1 \\
\hline
\end{tabular}

The data above indicates that the constructivist teaching model group had a higher mean score (72.6) and standard deviation (15.3) than their conventional model counterparts that had a mean (X) of 50.1 and S.D of 16.1

Hypothesis 1: There is no significant difference $(\mathrm{P}<0.05)$ between the mean scores of the SS physics students taught using constructivist teaching model and their counterparts taught using the conventional teaching model. Table 2 shows the z-test analysis of the SS physics students' achievement of both the constructivist and conventional model groups. 
Table 2: Z- test Analysis of the Mean Achievement Scores of both Groups.

\begin{tabular}{|l|l|l|l|l|l|}
\hline Group & $\begin{array}{l}\text { No. } \\
\text { Students }\end{array}$ & Mean (X) - & $\begin{array}{l}\text { Standard } \\
\text { Deviation }\end{array}$ & Z-cal \\
\hline $\begin{array}{l}\text { Constructivist teaching } \\
\text { model }\end{array}$ & 80 & 72.6 & 15.3 & 9.05 & 1.96 \\
\hline $\begin{array}{l}\text { Conventional teaching } \\
\text { model }\end{array}$ & 80 & 50.1 & 16.1 & \\
\hline
\end{tabular}

The result of Table 2 indicates that Z- calculated (9.05) was greater than the Z- table value (1.96) at 158 degrees of freedom. This implies that there is a significant difference between the group of students taught using the constructivist teaching model and their counterparts that were taught the same concepts using the conventional teaching model at 0.05 level of significance in favour of the constructivist group.

Research Question 2: what is the mean interest score of students towards physics when taught using constructivist model and their counterparts taught using the conventional model?

Table 3 shows the mean and standard deviation (SD) of both the constructivist group and conventional group interest toward physics study.

Table 3: Mean (X) and Standard Deviation (SD) of Interest Scores of Physics Students.

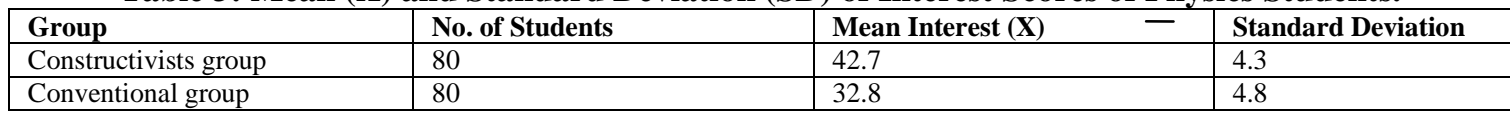

Results of Table 3 indicate that the constructivist teaching model group had a mean interest score of 42.7 with a standard deviation of 4.3 while their conventional teaching model group counterparts had a mean interest score of 32.8 with a standard deviation of 4.8 . This implied that physics students taught with the constructivist model have higher interest toward physics that those taught physics using the conventional teaching approach.

Hypothesis 2: There is no significant difference $(\mathrm{P}<0.5)$ between the mean interest scores of students taught physics using constructivist model and those taught using the conventional model.

Table 4: Z-test analysis of Students Interest Scores on Physics

\begin{tabular}{|l|l|l|l|l|l|}
\hline Group & No. of Students & Mean $(\mathrm{X})-$ & Standard Deviation & Z-cal & Z-table \\
\hline $\begin{array}{l}\text { Constructivist } \\
\text { teaching model }\end{array}$ & 80 & 42.7 & 4.3 & 13.8 & 1.96 \\
\hline $\begin{array}{l}\text { Conventional } \\
\text { teaching model }\end{array}$ & 80 & 32.8 & 4.8 & & \\
\hline
\end{tabular}

Based on the calculated Z-value (13.8) which is greater than the Z-table value (1.96), it means that the null hypothesis of no significant difference between the mean interest scores of the physics students taught using constructivist model and those taught using conventional model is rejected. In other words, there is a significant difference between the interest of the constructivist group and those of the conventional mode group at $\mathrm{P}<0.05$ level of significance in favour of the constructivist group.

\section{Discussion}

The analysis of the scores of the achievement of the students indicated that the constructivist group had a higher mean that their conventional counterparts. Also, a z-test analysis of the mean scores shoe that the difference observed was significant at 0.05 level of probability. By implication, constructivist teaching model has a positive effect on physics students' achievement. This finding is in line with the report of Obiekwe (2008) which indicated that constructivist teaching model was effective in facilitating students' achievement in sciences. It is also corroborated by Ogbonna (2002) who found that constructivist instructional model enhanced higher achievement and higher retaining level in mathematics content. Physics teachers at secondary schools are therefore enjoined to employ the constructivist model in their lesson instruction.

The analysis of the interest scores by both the constructivist and conventional group indicated a higher positive mean interest score in favour of the constructivist teaching model. The mean difference was found to be statistically significant at $\mathrm{P}<0.05$ level. The findings is in consonance with that of Ngwoke (1995) which found that interest aids memory leads to strong intent and achievement. By implication, the use of constructivist teaching model enhances performance and as well interest in physics. Constructivist model tends to provide the students with concrete learning experiences; hence students tend to be more interested because active involvement provides fun and greater development of manipulative skills. 


\section{Conclusion}

Constructivist model is a teaching model that upholds the principle of learning by doing. When this model is applied in physics teaching at secondary school, higher achievement and higher interest are enhanced. Since the constructivist mode is innovative and effective, physics teachers are enjoined to adopt it in the teaching physics.

\section{Recommendations}

From the findings of the study, the following recommendations are made.

1. Physics teachers at secondary schools should use the constructivist instructional model for effective and higher achievement as well as their interest

2. Constructivist instructional approaches like fieldtrip, laboratory method, cooperative be frequently used in teaching physics at the secondary school level.

3. That the school authority should sponsor fieldtrips and excursions to science related areas like hydroelectric power stations, Dams, science equipment development institutes among others. Such exercise would rekindle interest and enhance better performance of students in sciences.

\section{References}

[1]. Ngwoke, D.U. (1995). School Learning Theories and Applications. Enugu: Magnet Business Enterprise

[2]. Nwafor, O.M. (2007). Educational Innovation: Process and Products. Enugu: Magnet Business Enterprise.

[3]. Obiekwe, C.L. (2008). Effect of Constructivist Instructional approach on Students Achievement and Interest in Basic Ecological Concepts in Biology. Unpublished M.Ed. Thesis, U.N.N.

[4]. Offorma, G.C. (2009). Curriculum Implementation and Instruction. Onitsha: Uni-World Education Publishers Ltd.

[5]. Wikipedia, (2008).Constructivist Teaching Methods Retrieved on December, 9. http://en.wikipedia.org./wiki/constructivist teachingmethods. 